\title{
Between the Ethos of Science and the Ethos of Ideology*
}

\author{
DMITRI N. SHALIN \\ Columbia University
}

SOCIOLOGICAL FOCUS

Vol. 12 No. 4

October, 1979

\begin{abstract}
This paper attempts to explain the continuous friction between Marxist sociology and Marxist ideology in terms of the premises of the theory of scientific communism, which accords to proletarian ideology the status of scientific truth. The successive stages of the evolution of Soviet sociology are related to the parallel development of views on the scientific ethos. The notion of the "ethos of ideology" is introduced and applied to the analysis of the ideological turmoil Soviet sociology underwent in the course of its establishment as an academic discipline. "Value tolerance" is advocated as an alternative to the "value-partisan" and "value-neutral" orientations in social science.
\end{abstract}

$\mathbf{T}$

here is a certain parallel in the process of secularization of science in 17th century England and emancipation of Soviet sociology in mid-20th century Russia. What draws these two phenomena together is the socially structured ambivalence inherent in the ideologists' attitude toward the new institution which, along with its practical promise, carried the perennial threat to the established ideological monopoly. In both cases the emancipation of science from ideology followed a similar route. This can be seen in the heavy emphasis upon empiricism as the scientist's legitimate and indispensable tool in the search for truth; the claim that scientific findings have practical value for extending man's power over nature; the view of a scientific enterprise as coextensive with promotion of ideological beliefs or, to put it in the language of the 17 th century, propagatio fidei per scientia; and finally, transformation of a science into a relatively independent institution as a result of a largely unanticipated consequence of purposeful action.

These parallels may well be judged as superficial and obscuring the peculiarities of each historical case. But there is one thing that warrants more systematic comparison of the interrelationship between natural philosophy and theology at the time of the Renaissance and science and ideology in 20 th century communist society. What I have in mind is the propensity of ideologists to claim a scientific status for their tenets and the readiness of scientists to justify their enterprise in terms of their

*This is a revision of the paper presented at the 26th Annual Convention of the New York State Sociological Association, held in October, 1978, at Farmingdale. I wish to thank the organizers and the members of the Seminar on Sociology of Science at Columbia University who commented on an earlier draft of the manuscript. I owe a special debt of gratitude to Professor Robert K. Merton for useful criticisms and suggestions that were instrumental in preparation of the current version of the paper. 
ideological commitments. The history of Marxist science deserves special attention in this regard. Indeed, there seems to be a puzzling regularity with which the efforts to live up to the premises of Marx's theory lead to the resurrection of Marxism as a new ideology endowed with a supreme a u $^{\prime}$ ority over scientific and intellectual pursuits. Whenever Marxist theory has been established as an official guide to action, it has emerged as a substitute for ideology, as a scientific Weltanschauung equally binding for laymen and for professionals.

One common way to account for this recurrent pattern is to dissociate Marx's theory from its use and abuse in communist society by attributing the latter to the external political cirumstances prevailing in a given country. For instance, Stalin's abuse of power is held accountable for the excesses of ideological violence in Soviet science during the 1930's and 1940's (Graham, 1966; Joravsky, 1961; Medvedev, 1971). This entirely plausible explanation, however, tends to dismiss rather than systematically address the question of how the Marxian model of value-partisan science differs from the "scientific partisanship" practiced by social scientists in communist society.

The present paper suggests an alternative interpretation of the tensions between Marxist sociology and Marxist ideology, particularly between sociology and ideology in the USSR. It attempts to show that relatively autonomous scientific pursuits by Soviet sociologists became possible and continued up to the point where the division of labor between science and ideology was tolerated. The analysis proceeds on the assumption that the function generally accorded to Marxist theory in communist society is consistent with the theory of scientific communism, which elevates the proletarian ideology to the status of scientifically based truth. The central thesis holds that, where the science of society emerges as a substitute for ideology, it is prone to losing its function as a scientific theory and becoming a servant of power.

The fate of Soviet sociology has become an object of close scrutiny by Western scholars. Part of the reason for this is the hope that the case of Soviet sociology can lead to a better understanding of the status of academic sociology in the West. The central question of the ongoing debate is: under what conditions can sociology evolve as an independent discipline? Most of the works published so far have dealt with the progress of Soviet sociology in the 1960's (Labedz, 1963; Kassof, 1961, 1965; Merton \& Riecken, 1962; Feuer, 1964; Fischer, 1964, 1967; Parsons, 1965; Simiren ko 1966, 1969; Vucinich, 1968; Weinberg, 1974). A growing number of publications are devoted to the institutional progress of Soviet sociology in the 1970's (Simirenko, 1973, 1976; Shalin 1976, 1978; Zaslavsky, 1977; Dobson, 1977). Yet the theoretical significance of the recent confrontations between sociology and ideology in the USSR is far from clear. The present analysis attempts to reconsider the process of the academization of Soviet sociology in the light of the relations between Marxist sociology and Marxist ideology. To pursue this goal, I will concentrate on a discussion in the Soviet literature of the ethos of science and relate this to the successive stages of development of Soviet sociology into an academic discipline. But first, a few remarks on Marx's views of science and ideology are in order. 


\section{MARX ON THE PREMISES OF SCIENTIFIC WELTANSCHAUUNG}

It is common now to juxtapose the Comtean and Marxian positions linking the former to value-neutral (positivist) and the latter to value-partisan (critical) sociology. The differences between the two are undeniable. Where Comte aspired to lay a solid scientific foundation under the ideological program of action, Marx sought to humanize the social science by grounding its premises in value considerations. These all too familiar idealizations, however, tend to overlook the evolution undergone by both authors during the span of their careers. In some respects, the dynamic of the Comtean views is the reversed reflection of that of the Marxian. Comte started his independent career as an advocate of a pure science free of metaphysics and value considerations, grew increasingly more concerned with the question of values, and ended as a prophet of the future society and the religion of humanity. Marx proceeded in the opposite direction. Beginning with a philosophical-humanistic critique of contemporary science and society, he gradually moved from a prophetic stance to the attitude of a scientist who merely lays bare "natural laws . . . working with iron necessity towards inevitable results" (Marx, 1967a:8).

Given Comte's obsession with the "religion of humanity" in the Systeme de Politique Positive and Marx's fascination with the scientific method of political economy at the time of his working on Capital, it is anything but un problematic who of the two is a positivist and in what sense. One should exercise a good deal of caution when using familiar typifications that associate Comtean positivism with value neutrality and Marxian method with value-bound humanistic criticism. More fruitfully, we can assume that positivism from the very beginning sought to resolve the antinomy of pure and practical reason rather than to sever the ties between scientific and ethical concerns. In this sense, Marxian and Comtean analyses are equally positive. ${ }^{1}$

We will return to the dichotomy of positivist and critical sociology later. My purpose here is to emphasize the ambiguity endemic to the Marxian perspective on science and ideology.

Marx subjected to severe criticism contemporary social science as a form of bourgeois consciousness. Accusing classical political economy of serving the dominant ideological needs, he rejected as a myth the very idea of ideologically uncommitted science. And yet Marx was not only the most ideological among contemporary scientists; he was also the most scientific among ideologists. He strikes out Malthus for betraying the criteria of scientific analysis and adjusting the latter to ideological pressures of the day. "But I call base such a man," Marx remarks, "who seeks to adjust science to the standpoint that is taken not from science itself (however erroneous the latter may be) but from the outside, to the standpoint which is precipitated by interests alien, extraneous to science itself"' (Marx, 1967b:112). ${ }^{2}$ The positivist bent of this assertion is hard to conceal. Admittedly, it was Engels who coined the expression "scientific communism" and who was primarily responsible for an overly "scientistic" interpretation of Marx that undermined the humanistic underpinning of the early Marxian writings. Yet this interpretation was not entirely 
implausible. Following a conservative reading of Hegel, Marx repeatedly emphasized that the proletarian program of action is attuned to the "natural," "objective" laws of social evolution that are bound to bring about "inevitable results."

To resolve the contradiction, Marx advanced the thesis that the proletariat occupies a unique place among the historically ascending classes. What sets this class apart from all others is the truly universal nature of its appeal. The proletariat takes power only to vanish along with the other classes of capitalist society and to clear the way for the classless society of the future. The important corollary of this thesis is that the rise of the proletarian ideology means the end of ideology as an instrument of the advancement of particularistic class interests. Ideology now coincides with science inasmuch as it follows the pronouncements of a revolutionary teaching. The objective of this teaching is not only to discover "natural laws" but also to formulate an imperative for practical action. The new scientist openly admits his class commitments, though his partisanship or conscious adherence to proletarian values is a condition for, rather than impediment to, a search for truth.

Thus Marx merged in theory science and ideology. Their practical merger-first in the Soviet Union and then in the other East European countries-was far from theoretical expectations.

One can readily agree with Fischer (1967:ix) that the relationship between science and ideology in the Soviet Union is characterized by "harmony and mutual reinforcement;" however, it was the kind of harmony most detrimental to Marxist theory itself. As a student of reality, the Marxist scientist was required to revise his theory in view of the changing realities. In his capacity as a representative of the proletariat, he was expected to maintain constant vigilance against "revisionism" with regard to proletarian ideology. In practice, once the thesis was accepted and enforced that "the interests of our Party always correspond with objective scientific truth" (Emdin, 1947:11), the scholar's role as a student of reality was relegated to second place after his role as a class ideologue. The fusion of science and ideology resulted in a quick suppression of the empirical research begun by Soviet Marxists in the 1920's and the subsequent transformation of Marxist theory into "a truth that must be believed and enacted against all evidence to the contrary" (Marcuse, 1958:89).

The role conflict underlying the activity of Soviet scientists continued until 1956, when the 20th Congress of the CPSU endorsed relative autonomy for scientific enterprise. Nikita Khrushchev may not fully qualify for the role of a "Luther" of the Communist world, but his ideological reformation dealt a serious blow to Marxist orthodoxy and spurred the secularization of Marxist sociology. At first tacit but then progressively more manifest, the divergence of the ethos of science and the ethos of ideology precipitated the institutionalization of sociological research in the Soviet Union.

\section{THE ETHOS OF SCIENCE AND "CONCRETE SOCIAL RESEARCH"}

The new spirit established in Soviet social sciences is well conveyed by the editorial published in the theoretical organ of Soviet Marxism, Problems of 
Philosophy: "Rejecting the cult of personality, overcoming its evil consequences, the Party first of all opposes every effort to im pose any one standpoint as the only correct one and denounces rule by decree and incompetent interference in theoretical debates" (Editorial, 1965:6). Another editorial, eloquently entitled "For the Development and Strengthening of Ties Between Philosophers of Different Countries," instructed its readers:

Finally, personal contacts and correspondence are essential to strengthening ties and exchanging ideas and information. The experience of such contacts suggests that they enable philosophers of different countries better to understand each other, make for an atmosphere of trust and friendship between scientists... (Editorial, 1958:8).

After the years of "class vigilance" and struggle with "bourgeois sociology" these new pronouncements must have sounded like a major revision of social science policy. The new orientation was apparently revisionist, as shown by the attitude assumed by Soviet scholars toward their Western counterparts. Since Soviet sociologists began to participate in the World Congresses of Sociology in 1956, they became much more discreet in their criticism of bourgeois sociology. A member of the Soviet delegation to the Fourth World Congress of Sociology in Italy, P. N. Fedoseev assured his Western colleagues: "We are accused of not wanting to study Western sociology and particularly American sociology, but in truth, we are carefully following its course of development, and today we know more about it than yesterday, and tomorrow our knowledge will be even fuller" (Fedoseev, 1962:395).

All these declarations should not be understood to the effect that the principles of partisanship and class vigilance were discarded from the social scientist's vocabulary; however, the shift from the ethos of ideology to what Merton (1973) called "the ethos of science" was undeniable. The encouragement of cooperation between scholars from different countries indicated a shift toward the norm of "communism." The norm of "universalism" was underscored by the rejection of the "rule by decree." Criticism of "incompetent interference into theoretical debates" and denunciation of the monopoly established by certain schools in Soviet science reinforced the norms of "disinterestedness" and "organized scepticism."

Not surprisingly, the erosion of the principle of partisanship coincides with the shift in the stress from speculative to empirical methods of social research. The positivist bent of the new slogans can be readily discerned in the following appeal made immediately after the 20th Congress of the CPSU: "It is absurd to believe that philosophers can draw their conclusions by merely deducing some speculations from others by an abstract analysis of uncontestable truths. In particular, one has to put an end to the assumption that the specifics of philosophy consist in compiling one's works without leaving one's desk" (Editorial, 1956:16). To put this another way, social scientists were called upon to leave their armchairs, to get out on the streets, to the collective farms, and to see what "concretely" was going on there. The appeal to study social life concretely found its expression in "concrete social research." The latter was called upon to redefine the relationship between historical materialism and everyday life. As Academician Fedoseev (1968:8) unambiguously expressed the meaning of concrete social research: "The question of concrete sociological research is a question of fighting against dogmatism, against the scholastic understanding of 
historical materialism as a sum total of the canons given once and for all, which one cannot but comment upon and adapt to particular situations of time and space."

The new principles of scientific activity were codified in the statute of the Soviet Sociological Association founded in 1958. The second paragraph emphasized as a primary goal of Soviet sociologists "strengthening ties of Soviet scholars working the field of sociology with foreign sociologists and with international and national organizations in the best interests of the development of sociology" (O sozdanii..., 1958:185). Paragraph 10 pointedly stressed the need for an exchange of books between Western and Soviet sociologists.

During the first years of their work, Soviet sociologists vigorously denied any claim that sociology may have an independent value as a theoretical discipline in addition to classical Marxism. The first timid attempt made by the German Marxist Kuchinski (1957) where he pointed out that sociology has a value independent of the philosophical framework of historical materialism provoked a vigorous (though, characteristically for this time, polite) rebuke by his Soviet colleagues. This situation persisted until the early 1960's, when in 1963 Nikita Khrushchev, the first Secretary of the Central Committee, was suddenly dismissed. The campaign against "voluntarism" and for "the promotion of a scientific approach toward national economic problems" following his dismissal revived the discussion about the role of scientists in society. Soon afterwards, a complete change of leadership in the SSA took place, and in the late 1960's a decision was made to organize the Institute of Concrete Social Research in the system of the USSR Academy of Science. At the same time, discussion was renewed about the relationship between historical materialism and sociology.

\section{FROM CONCRETE RESEARCH TO MIDDLE-RANGE THEORY}

First to respond to the coming changes was the journal Problems of Philosophy. In its May issue editorial (1965), it renewed its criticism of incompetent interference in research activity. The main target of the criticism was the Stalinist period in Soviet science, though this time there was a clear allusion to the "voluntaristic" methods of leadership under Khrushchev. The unusual thing about this criticism was that for the first time the decisions of the earlier scientific sessions (on genetics, linguistics, and psychology) were openly denounced and officially discarded. ${ }^{3}$ This was hardly necessary, since earlier regulations and decrees were discarded de facto. The campaign had primarily symbolic value which underscored the new status of the scientist in communist society.

The editorial in Problems of Philosophy was followed by a number of critical publications. The most far-reaching of them was the article "On the ethics of a scientist" by Shishkin. The author contended:

\footnotetext{
The true Marxist must know that Marxism never established canonized requirements under which scientific investigation should operate. Marx and Engels did not want to have anything to do with Marxists who solved any problem by 'simply' deducing their solutions only from dialectics or who considered the materialistic understanding of history a pretext for not studying history itself. 'I am not a Marxist'-that is what Marx was saying in order to differentiate himself from such Marxists (Shishkin, 1966:18).
} 
The importance of the message contained in this article reached beyond criticism of interference in the realm of science. Wittingly or unwittingly, it reinforced the scientist's autonomy from political supervision and encouraged scientists to assume a critical stance with regard to ideology.

The campaign for the promotion of scientific methods of administration further undermined the authority of Marxist orthodoxy and stimulated a new generation of sociologists to engage in a struggle for power. This struggle turned into a battle to divide authority between historical materialism and sociology.

During the first years of social research in the USSR, Soviet scholars considered Marxist sociology a synonym for historial materialism. The only difference was the somewhat greater attention given to empirical data which were being supplied by concrete social research. As sociological research continued to advance in the 1960 's, the voices calling for a new status for Marxist sociology independent of the more speculatively oriented branches of Marxism became stronger. Some authors pointed out that the use of concrete data by scholars was going to continue to be performed perfunctorily and for the sake of mere illustration without the intermediary links between general sociological theory and concrete research. The need for middlerange theories was stressed by a number of authors who maintained that "the drawback of much special sociological research done in our country is that it is illustrative, i.e., it reinforces well-known, more or less general concepts, instead of coping with unsolved problems and giving practical recommendations" (Gvishiani, 1965:54).

The issue of middle-range theories was first raised by Andreeva (1962). At that time she rejected the idea as unacceptable for Marxist sociology. But a few years later, the idea of such theories (Soviet sociologists call them "special" or "particular") was reevaluated and tentatively endorsed by Iadov in 1966. According to the author,

Special sociological theories exist within the confines of the general theory-historical materialism-as its relatively independent divisions (subsystems of the general theory), such as the theory of social structure of personality. The insufficient development of these theories with respect to modern conditions . . . is the most serious impediment to the progress of concrete research (Iadov, 1966:30).

This formula proved to be acceptable to both the old guard philosophers and to the sociologists practically engaged in sociological research. In the eyes of the old school philosophers, this position reinforced their status as experts on general sociological theory and allowed them to retain some kind of supervisory function over specific theories which were understood to be derived from the general theory of historical materialism. For sociologists, the legitimation of specific sociological theories was tantamount to recognition of the independent theoretical value of sociology. This interpretation was reinforced by the publication of the two volume work, Sociology in the USSR. The preface to the second edition of the first volume stressed that a number of social sciences had already separated from philosophy and now "with some delay sociology is becoming recognized as an independent science" (Osipov, 1966:9).

The theoretical advances of Soviet sociology were followed by important 
organizational developments. At the general meeting of the Soviet Sociological Association held in February, 1966, the new generation of Soviet sociologists came to power. The central theme of the new leadership was that sociological theory and research can provide a scientific foundation for the formulation of Soviet policy. This stance fitted the framework of the Party campaign for a scientific approach to the problems of administration, and it came as no surprise when sociology received full endorsement at the special meeting of sociologists and Party officials held in Moscow in 1967 under the auspicies of the Academy of Sciences of the Central Committee. In the central report, entitled "On the Scientific Approach to the Party Ideological Work," a high Party official admitted:

Sociological research by its nature, orientation and results is especially valuable to the Party organs, to our Party. That is why in recent time it is more utilized in Party work. ... The objective of concrete research is to provide the Party apparatus with scientific recommendations aimed at improving its ideological work (Malin, 1967:3, 11).

If we compare the relationships between science and ideology in the late 1940's, at the peak of ideological interference in scientific activity, with the situation in the late 1960's, we cannot fail to see the contrast. Before the ideological reformation starting in 1956, the ethos of science was practically merged with the ethos of ideology, whereby the scholar's function as an ideologist impeded his activity as a scientist. The struggle with ideological "revisionism" effectively curtailed "revisionism" in science, where it informs the very foundation of daily knowledge production. In the late 1960's, ideologists came to admit that they suffered drawbacks in the implementation of policies based on the formulae of scientific Marxist-Leninist ideology, and had to grant a certain autonomy to scientists to whom they turned for recommendations. To be sure, no one in a position of power meant to give up or even to share policy-making prerogatives; however, even these changes might have had long-term consequences. For as soon as the division of functions (and authority) between science and ideology was recognized, scientists were placed, in fact forced, into a position that would allow them to test the premises of the grand theory.

\section{MARXIST SOCIOLOGY AND HUMANISTIC IDEOLOGY}

The unique characteristic of the research conducted by Soviet sociologists in the mid-1960's was that they set out to test hypotheses derived from Marxist theory. Their unique contribution consists in pointing to the gap between the theory and practice of communism, between Marxist ideology and the everyday reality of socialist society. The studies done by Soviet sociologists constitute an important evidence that Marxist theory is conducive to empirical testing. Whether a socialist system provides equal opportunity to different social groups and whether workers' alienation is solely a phenomenon of capitalist society are not only questions of theory but are also empirical questions.

One should be cautious when interpreting the findings of Soviet sociological research. Many of the studies carried out in the 1960's were theoretically weak and methodologically deficient. Most of them were conducted in the tradition of "concrete 
research." After isolating the problem, the author immediately proceeded to design the questionnaire, often completely omitting the step of defining concepts and formulating hypotheses. Each particular project should be judged on its own merit. Yet, even given their $a d$ hoc theorizing and dubious representativeness, the results had some theoretical value in that they demonstrated that there are problems in socialist society which are alien to its alleged nature and which cannot easily be reconciled with the premises of scientific communism.

Thus it is difficult to overlook the theoretical significance of the Novosibirsk study that led its authors to conclude that "... the paths of life of young people in different social groups at present differs substantially. Of 100 graduates from families of agricultural workers, only 10 continued their studies, while 90 went to work; of 100 graduates from families of the urban intelligentsia, 82 continued their studies and only 15 went to work" (Shubkin, 1965:66).

Neither can one deny the theoretical implications of the research conducted by Leningrad sociologists who contrasted the "communist attitude toward work" to the state of alienation of labor in capitalist society.

Marx's negative attitude toward the division of labor in society placed Marxist theoreticians in a rather awkward position since it implied that the division of labor is a transitory phenomenon which is bound to disappear with the establishment of public ownership of the means of production and subsequent spur to technological growth. But the data furnished by Marxist research clearly indicated that there is the growing disproportion between rising expectations of the young people finishing their 8-10 years in school with regard to the content of work and the backward rate with which this content is enriched in working professions (Zdravomyslov, Rozhin and Iadov, 1967:305). This finding was conspicuously at odds with their initial theoretical premise (p. 3) that the attitude toward work "is first of all determined by the complex of all social relationships, principally by the socio-economic nature of the society. ..." If we then take into account that the negative (noncommunist) attitude toward work was positively associated with the level of routinization of the performed function, we may well conclude that the prospects for overcoming alienation in communist society are uncertain at best.

It is not the purpose of this paper to enumerate the critical findings gathered by Soviet sociologists during the 1960's. ${ }^{4}$ (The evaluation of Marxist theory in the light of Marxist research should become an object of special analysis.) The point is that at least some of these findings, including data on the dynamics of crime in the USSR, on the political indifference of workers, and on the dynamics of religious beliefs among Soviet people, had a "serendipity effect" (Merton, 1968:168): they were anomalous results in clear contradiction to theoretical formulations that suggested the need for theoretical reorientation. Viewed separately the sociological data drew attention to the need for practical ways of overcoming the contradiction between theory and practice. Interpreted broadly, they questioned the accuracy of Marxist theoretical predictions and weakened the reputation of the official ideology as the scientific and universal one. The ideological implication of all these critical findings was a more tolerant attitude toward Western societies and the idea of dialogue with Western scholars. Take, for example, the opinion expressed by Rumiantsev, a member of the CPSU Central Committee and Director of the Institute of Concrete 
Social Research:

\begin{abstract}
Naturally, the Marxist partisan approach to the contest of ideas in science entails not only rejection of reaction, falsification, charlatanism where no compromise is possible, but also dialogue without which serious contacts are inconceivable. . . Our ideological principles and implacability do not mean that we communists are narrow sectarians and thick-skulled fanatics who divide all the world of scientific thought into black and white. . . Putting an end to dogmatism, we went on to constructive criticism, sober assessments, differentiation, analysis ... (Rumiantsev, 1968:12).
\end{abstract}

These exciting advances of Soviet sociology in the second half of the 1960's silenced the skeptics among Western sociologists and led Alex Simirenko to make a definitive projection of the growth of ideological tolerance (1966:33) for the next 10 to 20 years of Soviet sociology. The article by Rumiantsev entitled "The Humanistic Ideology and the Social Sciences" shows that this forecast stood on solid ground. Yet, as Marx repeatedly indicated, historical development goes in zig-zag fashion.

\title{
MARXIST IDEOLOGY VERSUS MARXIST SOCIOLOGY
}

In the early 1970's, the critical advances of Soviet sociology halted as abruptly as they had begun a decade before. The growing divergence between sociological findings and ideological needs soon became too apparent for ideologists to continue to ignore. Either ideology should have been modified in the light of the realities of Soviet society, or the scientific value of sociological findings should have been questioned. The professional ideologists reacted as had their predecessors in every time and epoch when their class interests were jeopardized.

An interesting aspect of the following campaign for the promotion of a partisan approach in sociology was that it was headed by the old-guard philosophers. In accordance with the rapidly changing political weather, they accused the emerging sociological elite of (a) attempting to separate concrete research from the general sociological theory of Marxism; (b) of betraying the principle of class-partisanship in scientific knowledge; and (c) of adopting deficient concepts from bourgeois sociology.

An open campaign against sociology was launched in 1970 in the theoretical journal of the Party, Kommunist, in which was carried an editorial strongly critical of the attempt to separate sociology from historical materialism and "to consider problems from the standpoint of abstract logicism devoid of the requirements of socio-political practice" (Editorial, 1970:69). In the following issue of the journal a noted Soviet philosopher, Glezerman, made a personal attack on the Soviet sociologist Levada, accusing him of drifting away from the position of class analysis (Glezerman, 1970:84). A year later, a group of authors, led again by Glezerman, analyzed the present stage of sociological research in the country and concluded that there was not sufficient attention and control over special sociological theory and concrete research. As a result, "the ensuing vacuum has sometimes been filled with theories and views uncritically borrowed from bourgeois sociology... The mistaken views can get currency and become widespread if the uncritical borrowings are not given a forceful rebuff' (Glezerman, Kelle, and Pilipenko, 1970:68).

The year 1971 marked a turning point in Soviet sociology with the resignation of the Director of the Institute of Concrete Social Research, Academician Rumiantsev. 
The Central Committee empowered a special commission to inquire into the state of scientific and ideological progress at the Institute. During the course of this inquiry some leading scholars received reprimands from the Party. The commission referred to the low practical effectiveness of sociological research and the unsatisfactory conditions of ideological work in the Institute (IKSI AN SSSR, 1972).

Shortly afterwards, M. N. Rutkevich, a corresponding member of the Soviet Academy of Science, was appointed Director of the Institute. In violation of the SSA statutes, he cancelled the already assembled general meeting of the Soviet Sociological Association, dismissed certain delegates and nominated others, and finally, convened a new conference which elected Rutkevich President of the SSA (Zemtsov, 1976).

The change in leadership lent new impetus to the campaign against errors in sociology. In 1972, the exodus of sociologists from the Institute and other sociological centers began. According to an official report, there were 12 leaders of top research divisions of the Institute in 1971. During the period 1972 to 1974, nine of them left the Institute (IKSI AN SSSR, 1972). The next step was a call for purity in the conceptual schemes of Marxist sociology. Notions such as social stratification, social mobility, reference group, and role were attacked as bourgeois terminology. The critics called for an end to "the practice of reasoning about 'systems,' 'subsystems,' 'system qualities,' 'overlapping structures,' etc., which are so far from the generalization and theoretical analysis of modern society, from the needs of ideological struggle, from practical experience and organizational activity of the Party" (Iagodkin, 1957:11). In 1972, a number of previously published sociological monographs were confiscated and destroyed (Zemtsov, 1976; Rabbot, 1977).

One could readily draw parallels between the developments in Soviet sociology and the earlier conflicts between science and ideology. It is more important to point to the similar patterns of the assault on the ethos of science that characterized Soviet science in the 1940's and marked its progress in the 1970's. In contrast to its earlier declarations, the journal Problems of Philosophy tells us that partisanship "means a conscious effort to advance the interests of the working class, its needs and objectives in its revolutionary struggle for socialism and communism. And since these interests coincide with the objective laws of social development, partisanship in Marxist-Leninist philosophy coincides with the search for scientific truth" (Editorial, 1974:47). Once again we hear the startlingly familiar appeal to insure the opportunity for unrestrained criticism and self-criticism and "to maintain the purity of Marxism-Leninism, the class-bound, partisan approach in social sciences," made by the new head of the Central Committee Department of Science in the USSR (Trapeznikov, 1973:28). With the triumph of partisanship, Soviet sociology entered a period of speedy academization.

\section{GOULDNER'S THESIS OR THE ETHOS OF IDEOLOGY REV ISITED}

Given recent trends in Soviet sociology, the evidence supporting Gouldner's thesis about converging trends in Marxist and Western sociology should be judged marginal. One part of this thesis, which suggests that sociology is allowed to establish itself as an academic discipline only "when the elites of society are 
confident that its social scientists are, in fact, not neutral" (Gouldner, 1970:470), seems to be confirmed by Soviet experience. We witness the remarkable correlation between the progress of Soviet sociology as an academic discipline and its growing dependence on ideology. The growing recognition of Soviet sociology as an academic discipline and a profession in the 1970's is seen in (1) the establishment of the first sociological journal, Sociological Research, in 1974; (2) the change of the title of the Institute, which was renamed the Institute of Sociological Research; (3) the establishment of graduate and undergraduate degrees in sociology; and (4) the expansion of sociological research, which is now characterized by greater technical sophistication (Shalin, 1978).

On the other hand, in contradiction to the idea advanced by Gouldner, the academization of Soviet sociology shows a reverse correlation with the attitude toward functional theory. With the beginning of the drive for partisanship, the structural-functional paradigm was among the first to come under attack, and charges against it were, ironically, similar to those advanced by Gouldner. ${ }^{5}$ As Simirenko (1973) noticed, the new course of sociological research in the Soviet Union indicates a divergence from the orentation of Western sociology. The latter is characterized by a proliferation of alternative programs for sociology. There is no general sociological theory which would be obligatory to the members of the sociological community in the West, whereas Marxist theory remains the uncontestable foundation of sociological activity in the Soviet Union and most East European countries. One could argue that there is a growing concern with the question of values and sociologists' responsibilities for the social consequences of scientific knowledge found among Western sociologists. Yet most sociologists in the West would agree that the question of values, while worth pursuing, cannot be solved once and for all on the basis of scientific considerations. It seems unlikely that even the most ardent proponents of partisanship among sociologists in capitalist countries would side with the following principle, advanced by the first textbook of sociology published in the USSR:

The interests of our Party correspond to the objective laws, tendencies of societal development. That is why partisanship in Marxist-Leninist sociology is, at the same time, a guarantee of its scientific value (Osipov, 1976:12).

If we take communism, universalism, disinterestedness, and organized scepticism as constituent elements of a scientific ethos (Merton, 1973:254-66), then we can see that each of these norms has undergone a targeted modification in the course of the campaign for the partisan approach in Soviet sociology.

Communism, or the assumption that scientific products are essentially the result of social collaboration and international division of labor, and as such should be available to every member of the community, was replaced by the principle of privatism. The latter $\mathrm{emphasizes}$ the unique contribution of national scholars to the treasury of scientific knowledge and is accompanied by secretiveness and deliberate measures to protect the free flow of "unauthorized information." (A relatively pure case of privatism is Stalin's campaign against "cosmopolitism" in Soviet science. In the current decade, this principle is illustrated by the massive drive to classify earlier Soviet studies and the researches in progress.) 
Universalism, which asserts that "truth claims, whatever their source, are to be subjected to preestablished impersonal criteria" (Merton, 1973:270), was replaced with a kind of imperialism that insists on class criteria for truth which could be used arbitrarily by the ideological authorities and that seeks to impose one theoretical paradigm on all the practitioners of a given discipline as the paradigm for the production of scientific knowledge. (The reaffirmation of the Communist Party authority in questions of truth and suppression of the non-orthodox theoretical currents such as structural-functionalism exemplify the principle of imperialism.)

Disinterestedness, or the expectation that personal interests will not lead one to faking evidence or suppressing rival views is replaced by the principle of partisanship which stimulates the promotion of group interests and may result in the emergence of scientific school establishments. (The latter principle is illustrated by the attempt to stamp out critical sociological data about Soviet society and by the well orchestrated attack on certain sociological centers in the USSR, which in some cases led to their termination or complete restructuring.)

And finally, organized scepticism finds its logical counterpart in organized ostracism or the collective denunciation of those who adopted improper views. (The latter principle can be seen in the public campaigns aimed at discrediting liberal Soviet sociologists.)

The objection can be raised that the combination of privatism, imperialism, partisanship and organized ostracism is only a caricature, a distorted reflection of reality that does not represent the complex interaction between Soviet sociology and ideology, and is plainly inapplicable to the situation in the West. To this it can be said that norms of scientific ethos are never fully observed, even in those countries which have most reason to be proud of their scientific freedom. To ignore this is to confuse psychological and sociological levels of analysis. It also should be clear that the notion of ideology is used here in the strictly Marxian sense. It refers to the activity having the manifest function of promoting ideas, symbols, and slogans that transcend the interests of particular groups, whereas the latent function of this activity is to conceal the fact that some of those involved benefit more than others from the suggested line of action.

Far from reflecting reality in its totality, the ethos of science and the ethos of ideology are two analytical concepts which comprise an ideal continuum for the description of what, following orthodox Marxist tradition, we can call scientific and ideological modes of thought. This distinction applies not only to social sciences, but also to their natural counterparts. The elevation of a truth claim to the status of a certified truth has practical implications not only because it can lead to the reallocation of funds, changes in scientific policies, and the emergence of scientific school establishments, but also because the social consequences of scientific discoveries can affect the life of the whole population and can challenge or reinforce the dominant world views. This connection was manifest repeatedly during the early confrontations between science and theology, and it has dramatically surfaced in the recent conflict between Marxist sociology and Marxist ideology. The problems faced by Soviet sociologists are not dissimilar to those met by scientists in the formative stages of the development of science. The division of labor between science and ideology tacitly endorsed by the 20th Congress of the CPSU had eventually 
reached the point where a confrontation between the two became unavoidable. This conflict grew into a battle in which ideology emerged as the decisive victor. The ideologists once again managed to evade responsibility for value choice by proclaiming their positions scientifically valid; sociology was allowed to establish itself as an academic discipline on the condition that the ethos of science be merged with the partisan ethos of ideology; Marxist-Leninist ideology was reinforced in its traditional role as the general sociological theory that meets the high standards of scientific truth; and scientists, after taking refuge in self-criticism, were confirmed in their prestigious role as its trusted guard and propagandist.

\section{VALUE PARTISANSHIP, VALUE NEUTRALITY, AND VALUE TOLERANCE}

Recapitulating the development of sociology in the Soviet Union for the 20 years of its existence, one can point to the correlation between the ideological changes in the country, the discussion about the ethos of scientific work, and the parallel evolution of Marxist sociology into an academic endeavor: (a) The undermining of the principles of partisanship and class vigilance after the 20th Congress of the CPSU coincides with the denunciation of ideological interference in scientific activity, with the criticism of dogmatism in the social sciences, and precipitates an interest in empirical methods of sociological investigation; (2) the campaign against voluntarism and for the promotion of a scientific approach to national economic problems revives the discussion about the scientist's role in society with a new emphasis on the relative autonomy of scientific pursuits, and is reflected in the process of secularization of Soviet sociology; (3) the shift in Party policy toward strict ideological control over science correlates with the relegation of the ethos of science to a position in the service of the ethos of ideology, the subordination of Marxist sociology to Marxist ideology with subsequent legitimation of that sociology as an academic discipline.

The fate of Soviet sociology brings us back to the question raised in the beginning of this paper: why did the efforts to live up to the premises of Marx's theory end with the resurrection of Marxism as a new ideology?

Marx's whole life as a scientist was concentrated on endeavoring to bridge the gap between science and morality, pure and practical reason, value and truth-the gap that kept growing since the scientific mind turned against religion, and that reached its highest point at the age of rationalism and the Enlightenment. Marx's theory may be viewed as a desperate quest for the original wholeness of the religious ethos which did not know the breach between man's rational comprehension of the universe and his practical orientation. As many authors came to notice, the Marxian paradigm of social history bears a striking affinity to the Judeo-Christian picture of man's destiny. Indeed, Marx's vision of the social universe as a separation of labor and enjoyment, production and consumption, private and public, mental and physical, authentic and fractionalized existence is, in some respects, a theoretical extension of the Christian view of history as a process of man's alienation from the Creator: man is damned to labor as atonement for the Original Sin and is predestined to recapture the paradise lost some time in the future. 
Marx's theory of social development as a lawful evolution toward a transcendental goal-communism-is clearly providential. What makes his views differ from the religious philosophy of history and at the same time draws it closer to the ideals of the Enlightenment is a belief in the active role of scientific knowledge. A similar concern is characteristic of the whole tradition of 19 th century positivism that sought to establish science as an arbiter in the dispute over values. It underlines the Comtean search for the new science of society and the true religion of humanity as much as Marx's quest for the synthesis of value and truth. The practical results of the attempted merger of science and ideology were both unanticipated and ironic.

There is little doubt that the present day reality of science and ideology in communist society differs radically from Marx's ideals and would be repugnant to his conscience as a scientist. Yet even a man of Marx's genius could not foresee the unanticipated consequences of rational considerations. He could not predict that his attempt to commit social science to certain values would lead to the apotheosis of science as an ideology, to the rise of "scientific ideology." Scientific ideologists put science at its complete disposal. They nurture and support science because they expect to use it as a means to attain ultimate ends and mostly to the extent that it serves these ends. And once ends themselves are scientifically consecrated, every means may be legitimized for making practice meet the requirements of scientific theory. All too often the dream of the "last violent deed" has materialized into permanent violence when a truth claim was justified by the claimer's position in society.

Marxist tradition in sociology is rightly associated with the scientist's responsibility for the social consequences of knowledge. It is this side of Marx's teaching that is a source of recent emphasis on a religious dimension of science and on the priestly functions of scientists. Given the salient role played by scientists in policy formation and the radical separation of laymen from professionals in the age of science, one can readily elevate this analogy to the status of homology. Although highly revealing of the common roots of modern science and religion, this metaphor is misleading in one respect. Religion is a partisan institution. It rests on the monopoly of ultimate truth and is characterized by the intolerance to the competing "religious paradigms" for extracting sacred sense from mundane reality. The ascent of science, whatever its original rationale and relapses into the theoretical hegemonism, carried with it the recognition of the historical and social nature of truth and encouraged the tolerance of competing values. What makes the religious ethos differ from the ethos of science is, above all, the attitude toward "revisionism." Being an institutionalized norm of scientific ethos, revisionism is still much of a scourge among most of the members of the theological community, who perceive it as a source of disastrous schism. The conversion of science into a "monastery" and scientists into "priests" serving the interests of a "chosen class" is coterminous with ideological intolerance and may result in theoretical stasis.

This precept suggests an alternative perspective on the controversy over value partisanship and value neutrality. It cuts across existing divisions by furnishing grounds for value-tolerant science. The possibility of such an orientation is suggested by Mannheim's perspectivistic approach outlined in his Ideology and Utopia. The value-tolerant orientation stems from the assumption that value 
concern and value detachment are equally indispensable to sociology. Value tolerant science accepts the Marxian thesis that knowledge bereft of social consequences and mundane interests is a misnomer, yet it rejects scientific partisanship as an attempt to hypostasize one particular value position into the only legitimate locus of truth. It gives up efforts to free science from ethical considerations as positivistic scientism tries to do, but at the same time it orients toward overcoming the narrowness of one's inherited class commitments. The role of a scientist as a member of an "anticlass," which Mannheim called "intelligentsia," is of the utmost importance; not because a scholar is chronically uncommitted, but rather because the scholar can identify him/herself with more than one cause at once, transcend the borderlines of existing class divisions, and open up new value perspectives. It is through this creative ability to alienate oneself from any given class-identity as partial and contingent or, to paraphrase Mead, to take the value perspective of the other that the scholar fulfills his/her function as a member of the community as such. The ongoing transcendence of one's class commitments and bridging of the diverse and conflicting value perspectives may help to retain what is valuable in Weber's "value-neutrality" without sacrificing Marx's value-bound humanistic criticism.

The objective of value tolerance is not to overcome the contradiction between competing loyalities to universal values of science and to particularistic needs of ideology, but to encourage and institutionalize the ongoing conflict between science and ideology as a precondition for their peaceful coexistence. Ideology need not become a science in order to cease to be a false-consciousness; it is enough to make its latent function manifest, i.e., openly to admit that it serves particular interests without thereby claiming their universal value and denying the right of other groups (real or potential) to advance their particularistic interests. In the same vein, one need not deny the scientist's right to adhere to specific values in order to "deideologize" science; it is enough to recognize that the division of labor and therefore conflict between science and ideology, between man's moral and scientific commitments, is indispensable for the democratic as well as for the scientific process. The substitution of one for the other may have equally grave consequences, as Max Weber long ago pointed out. Science must ascertain usually unanticipated consequences of ideological decisions, but it is not a valid foundation for ethical choice; human values are a factor in the selection of scientists' problems and methods, but ethical reasons are not a valid foundation for adopting or rejecting scientific hypotheses.

A final remark on the future of sociology in the USSR is in order here. Despite the events of the current decade, Soviet sociology has emerged as a discipline, and as a social institution it seems here to stay. The attitude of the ideologists to this fact may vary, but sociological information on social processes in the society is as indispensable to the Soviet state as were the practical achievements of physical science to 17 th century society. After all, it took two centuries for science to insure fully its independence as a social institution. Remembering that Soviet sociology has just celebrated its 20 th anniversary, let us end this story with a note of hope. 


\section{FOOTNOTES}

1. It is not inconceivable, as some authors suggest (Rex, 1973; Smart, 1976), that Marx, despite his pejorative comments on Comte, was directly or indirectly influenced by his ideas.

2. Compare this statement to another made by Durkheim some thirty years later: "All preconceptions must be eradicated.... The sociologist ought, therefore, whether at the moment of the determination of his research objectives or in the course of his demonstration, to repudiate resolutely the use of concepts originating outside of science for totally unscientific needs" (1964:31-2).

3. Problems of Philosophy published the following comments on the period of ideological dominance in Soviet science: "During the VASKhNIL [AIl Union Academy of Agricultural Sciences] meeting (1948), in the course of discussion on the problems of linguistics (1950), throughout Pavlov's congress (1950), correct statements were often rejected "offhand" and some mistakes grossly exaggerated. Many scientists were denied the opportunity to formulate and defend their views and conclusions. . . In this atmosphere the temptation built up to "back oneself" with the authority of the official position by using it as a final argument" (Editorial, 1965:6).

4. The results of some other critically important studies of the 1960's are discussed in Lipset (1973), Dobson (1977), and Shalin (1978).

5. This similarity does not invalidate Couldner's analysis of Parsons' functionalism (although it could be challenged on other substantive grounds, e.g., as being overly functionalist). But the thesis about the converging trends in Marxist and Western sociologies as advanced by Gouldner definitely requires revision in the light of recent developments.

\section{REFERENCES}

Andreeva, G. M.

1962 Burzhuanaia Empiricheskaia Sotsiologiia v Poiskakh Vykhoda iz Krizisa. Filosofskie Nauki 5.

Dobson, R. B.

1977 "Mobility and stratification in the Soviet Union." Annual Review of Sociology 3:297-330.

Durkheim, E.

1964 The Rules of Sociological Method. New York: Free Press.

Editorial

1956 XX Sezd KPSS i Voprosy Ideologicheskoi Raboty. Voprosy Filosofii 2:3-18.

1958 Za Razvitie i Ukreplenie sviazei mezhdu filosofami raznykh stran. Voprosy Filosofii 2:3-8.

1965 Razvivat Leninskii Stil $v$ Filosofskikh Issledovaniiakh. Voprosy Filosofii 4:3-8.

1970 Kommunisticheskaia Partiinost: Vazhneishii Printsip MarksistkoLeninskoi Filosofii. Kommunist 3:65-79.

1974 S Pozitsii Partiinosti. Voprosy Filosofii 1:47-56.

Emdin, M. V.

1947 Speech delivered during the discussion on "History of Western-European Philosophy" by G. V. Alexandrov. Voprosy Filosofii 1:6-13.

Fedoseev, P. N

1962 Kommunizm i Filosofiia. Moskva:
Akademiia Nauk SSSR.

1968 Sotsiologicheskie Issledovaniia v SSSR. Sotsialnye Issledovaniia: Obshchie Problemy 2:5-26.

Feuer, L. S.

1964 "Problems and unproblems in Soviet social theory." Slavic Review 23:117-24.

Fischer, G.

1964 Science and Politics: The New Sociology in the Soviet Union. Ithaca, NY: Cornell University Press.

Fisher, G. (ed.)

1967 Science and Ideology in Soviet Society. New York: Atherton.

Glezerman, G. E.

1970 Istoricheskii Materializm i Problemy Sotsialnykh Issledovanii. Kommunist 4:76-87.

Glezerman, G., V. Kelle, N. Pilipenko

1971 Istoricheskii Materializm: Teoriia Nauchnogo Poznaniia i Revolutsionnogo deistviia. Kommunist 4:60-70.

Gouldner, A. W.

1970 The Coming Crisis of Western Sociology. New York: Basic Books.

Graham, L, R.

1966 Science and Philosophy in the Soviet Union. New York: Knopf.

Gvishiani, D. M.

1965 Istoricheskii Materializm i Chastnye Sotsiologicheskie Issledovaniia. Voprosy 
Filosofii 5:47-56.

Iadov, V. A.

1966 Rol metodologii v Opredelenii Metodovi Tekhniki Konkretnogo Sotsiologicheskogo Issledovaniia. Voprosy Filosofii 10:26-47.

Iagodkin, V. N.

1975 Razrabotka Problem i Propaganda Sotsialisticheskogo Obraza ZhizniVazhneishaia Zadacha v Usloviiakh Sovremennoi Ideologicheskoi Borby. IKSI AN SSR Sotsiologicheskie Issledovaniia 1:9-18.

1972 Otchet o Rabote Instituta Konkretnykh Sotsiologicheskikh Issledovanii za 1971 God. Moskva: Institut Konkretnykh Sotsiologicheskikh Issledovanii.

Joravsky, D,

1961 Soviet Marxism and Natural Sciences 1917-1932. New York: Columbia University Press.

Kassof, A.

1965 "American sociology through Soviet eyes." American Sociological Review 30:114-21.

1961 "Moscow discovers public opinion polls." Problems of Communism 10:52-54.

Labedz, L.

1956 "Soviet attitude to sociology." Soviet Survey 10:6-15.

Kuchinski, U.

1957 Sotsiologicheskie Zakony. Voprosy Filosofii 5:95-100.

Lipset, S. M.

1973 "Soviet stratification research and Soviet scholarship." In M. Yanovich and W. A. Fisher (ed.), Social Stratification and Mobility in the USSR. White Plains, NY: International Arts and Sciences Press.

Malin, V.N.

1967 O Nauchnom Podkhode k Partiino Ideologicheskoi Rabote. Pp. 1-14 in Sotsiologiia i Ideologicheskaia Deiatelnost. Moskva: AON.

Marcuse, $\mathrm{H}$.

1958 Soviet Marxism: A Critical Analysis.

Marx, K. New York: Columbia University Press.

1967a Capital. Vol. 1. New York: International Publishers.

1967b Theorien des Mehrwert, Karl Marx und Friedrich Engels. Werke, Band 26, Zweiter Teil. Berlin: Dietz Verlag.

Medvedev, R. A.

1971 Let History Judge: The Origin and Consequences of Stalinism. New York: Vintage.

Merton, R. K.

1968 Social Theory and Social Structure. New York: Free Press.

1973 "Science and the social order." Pp. 254-66 in The Sociology of Science, N. W. Storer (ed.), Chicago: The University of Chicago Press.

Merton, R. K. and H. W. Riecken

1962 "Notes on sociology in the USSR." Current Problems in Social-Behavioral Research. Washington, D. C.: National Institute of Social and Behavioral Science.

Osipov, G. V. (ed.)

1966 Sotsiologiia v SSSR. Tom 1. Moskva: Nauka.

1976 Rabochaia Kniga Sotsiologa. Moskva: Nauka.

O Sozdanii . . .

1958 O Sozdanii Sovetskoi Sotsiologicheskoi Assotsiatsii. Voprosy Filosofii 8:185-86.

Parsons, $\mathrm{T}$.

1965 "An American impression of sociology in the Soviet Union." American Sociological Review 30:121-25.

Rabbot, B.

1977 "A letter to Brezhnev." The New York Times Magazine, Nov. 6.

Rex, J.

1973 Discovering Sociology. London: Routledge and Kegan.

Rumiantsev, A. M.

1968 Gumanisticheskaia Ideologiia i Sotsialnye Nauki. Voprosy Filosofii 11:313.

Shalin, D. N

1976 "On current trends in Soviet sociology." La Critica Sosiologica 38:173-84.

1976 "The development of Soviet sociology, 1956-1976." Annual Review of Sociology 4:171-191.

Shishkin, A. F.

1966 Ob Etike Uchenogo. Voprosy Filosofii 2:14-25.

Shubkin, V. N.

1965 Molodezh Vstupaet $\mathrm{v}$ Zhizn. Voprosy Filosofii 5:57-70.

Simirenko, A. (ed.)

1966 Soviet Sociology: Historical Antecedents and Current Appraisals. Chicago: Quadrangle.

1969 Social Thought in the Soviet Union. Chicago: Quadrangle.

Simirenko, A.

1973 "Soviet and American sociology in the seventies." Studies in Comparative Communism 6:25-50.

1976 Sociology in the Soviet Union: The State of the Discipline. Presented at Annual Meeting of Canadian Sociological Association. Quebec City.

Smart, B.

1976 Sociology, Phenomenology and Marxian Analysis. London: Routledge and Kegan.

Trapeznikov, S. T. 
1973 Marsistsko-Leninskaia Filosofskaia Nauka i Sovremennost. Voprosy Filosofii 8:16-30.

Vucinich, A.

1968 "Science and morality: A Soviet

Weinberg, E. A. dilemma." Science 159:1208-12.

1974 The Development of Sociology in the Soviet Union. London: Routledge and Kegan.

Zaslavsky, V.

1977 "Sociology in the contemporary Soviet
Union." Social Research 44:330-53.

Zdravomyslov, A. G., V. P. Rozhin, and V. A. Iadov 1967 Chelovek i Ego Rabota. Moskva: Mysl.

Zemtsov, I.

1976 IKSI: The Moscow Institute of Applied Research. A Note on the Development of Sociology in the USSR. Soviet Institutions Series, No. 6. Jerusalem: The Soviet and East European Research Center of the Hebrew University of Jerusalem. 